
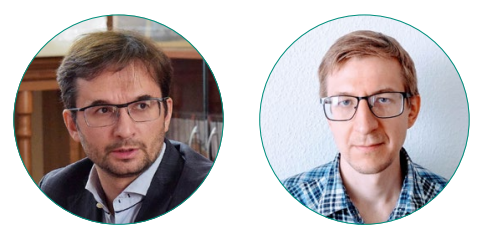

А. Б. Белоусов, Д. А. Давыдов

\title{
ОТ ПРАВА НА ГОРОД К ПРАВУ НА ПРОСТРАНСТВО. ДИНАМИКА МУНИЦИПАЛЬНЫХ КОНФЛИКТОВ НА ПРИМЕРЕ СВЕРДЛОВСКОЙ ОБЛАСТИ
}

\section{Правильная ссылка на статью:}

Белоусов А.Б., Давыдов Д. А. От права на город к праву на пространство. Динамика муниципальных конфликтов на примере Свердловской области // Мониторинг общественного мнения: экономические и социальные перемены. 2021. № 6. С. 362-385. https:// doi.org/10.14515/monitoring.2021.6.2052.

\section{For citation:}

Belousov A. B., Davydov D. A. (2021) From the Right to the City to the Right to Space. Dynamics of Municipal Conflicts on the Example of the Sverdlovsk Region. Monitoring of Public Opinion: Economic and Social Changes. No. 6. P. 362-385. https://doi.org/10.14515/monitoring.2021.6.2052. (In Russ.) 
ОТ ПРАВА НА ГОРОД К ПРАВУ НА ПРОСТРАНСТВО. ДИНАМИКА МУНИЦИПАЛЬНЫХ КОНФЛИКТОВ НА ПРИМЕРЕ СВЕРДЛОВСКОЙ ОБЛАСТИ

БЕЛОУСОВ Александр Борисович кандидат политических наук, старший научный сотрудник, Институт философии и права УрО РАН, Екатеринбург, Россия

E-MAIL: ektb@ya.ru

https://orcid.org/0000-0003-0082-909X

ДАВыДОВ Дмитрий Александрович кандидат политических наук, научный сотрудник отдела философии, Институт философии и права УрО РАН, Москва, Россия

E-MAIL:davydov_ifp@mail.ru

https://orcid.org/0000-0001-7978-9240

Аннотация. В статье изложены результаты исследования динамики городских/муниципальных конфликтов на примере Свердловской области, проведенного с помощью ивентанализа. Изучено 208 конфликтных событий за период с начала 2006 г. до середины 2021 г. Количественный анализ дополнялся изучением отдельных кейсов в сравнительной перспективе с целью выявления качественных изменений (ключевые агенты гражданской мобилизации, их политическая принадлежность и т.д.). Отмечено, что после 2010 г. в Свердловской области наблюдается резкий подъем конфликтной активности, связанной с оспариванием муниципальных территорий (преимущественно городские конфликты). Исследование показало, что в последние годы чаще всего конфликты разгораются вокруг таких пространств, как парки, скверы, площади и прочие публичные город-
FROM THE RIGHT TO THE CITY TO THE RIGHT TO SPACE. DYNAMICS OF MUNICIPAL CONFLICTS ON THE EXAMPLE OF THE SVERDLOVSK REGION

Alexandr B. BELOUSOV ${ }^{1}-$ Cand. Sci. (Polit. Sci.), Senior Researcher

E-MAIL: ektb@ya.ru

https://orcid.org/0000-0003-0082-909X

Dmitriy A. DAVYDOV ${ }^{1}$ - Cand. Sci. (Polit. Sci.), Research Fellow

E-MAIL: davydov_ifp@mail.ru

https://orcid.org/0000-0001-7978-9240

1 Institute of Philosophy and Law of the Ural Branch of
the Russian Academy of Science, Ekaterinburg, Russia

Abstract. The article presents the results of a study of the dynamics of urban/municipal conflicts on the example of the Sverdlovsk region, conducted with the method of event analysis. Research is based on the analysis of 208 conflict events from the beginning of 2006 to the middle of 2021. We supplemented the quantitative analysis with the study of individual cases in a comparative perspective to identify qualitative changes (key agents of civil mobilization, their political affiliation, etc.). The article notes that after 2010 in the Sverdlovsk region, there has been a sharp increase in conflict activity related to the contesting of municipal territories (mainly urban conflicts). A trend for increasing the effectiveness of local protests has been found - after 2013, the share of protests that bring positive results to activists increased sharply and became predominant. We found out that the success of the struggle of civil activists against the initiatives 
ские места. Обнаружена тенденция к росту результативности локальных протестов: после 2013 г. доля протестов, приносящих активистам положительный результат, резко растет и становится преобладающей. Обнаружено, что успех борьбы гражданских активистов против инициатив бизнеса и власти (“машины роста») в значительной степени зависит от того, с какого типа территориями и объектами они имеют дело.

Наибольшая доля успешных протестов наблюдается в случаях борьбы за парки, скверы, площади, публичные городские пространства, а также за леса, загородные водоемы и против вредных производств. Минимальная вероятность успеха отмечается у протестов против уплотнительной застройки и за сохранение исторических и архитектурных памятников. Качественный анализ информации о конфликтах показал, что налицо тенденции к деперсонификации протеста и "низовой" самоорганизации, а также все большее внимание активистов к деталям оспариваемых проектов. Учитывая возросший интерес у протестующих (в том числе урбанистов) к эстетической составляющей городского пространства, можно предположить, что локальные конфликты, скорее всего, тематически будут связаны преимущественно с зелеными пространствами и историко-культурной ценностью тех или иных объектов и территорий. Поэтому сочетание "спроса на эстетику" и слабой реакции бизнеса и власти на протесты за сохранение исторических и архитектурных памятников представляется одним из сохраняющихся рисков роста протестной активности. of business and government (neoliberal "growth machines") largely depends on what type of territories and objects they are dealing with.

The largest share of successful protests has been in cases of the struggle for parks, squares, public urban spaces, as well as for forests, suburban reservoirs, and against harmful industries. The minimum probability of success is fixed in protests against infill development and preserving historical and architectural monuments. Based on qualitative analysis of information about conflicts, we conclude that there are trends towards the depersonalization of protests and the growth of "grassroots" self-organization and greater attention of activists to the details of contested projects. Given the increased interest among protesters (including urbanists) in the aesthetic component of urban space, local conflicts are likely to be thematically related mainly to green spaces and the historical and cultural value of particular objects and territories. Therefore, the combination of "demand for aesthetics" with the weak reaction of business and local authorities to protests to preserve historical and architectural monuments seems to be one of the persisting risks of an increase in protest activity. 
Ключевые слова: городские конфликты, муниципальные конфликты, право на город, политическая мобилизация, гражданское общество, протестные акции, урбанистика

Благодарность. Статья подготовлена в рамках работы по проекту РФФИ № 20411-660027 "Мониторинг и прогнозирование социальных конфликтов в Свердловской области в 20202022 гг."
Keywords: urban conflicts, municipal conflicts, the right to the city, political mobilization, civil society, protest actions, urbanism

Acknowledgments. The article was prepared as part of the work on the RFBR project No. 20411-660027 "Monitoring and forecasting social conflicts in the Sverdlovsk region in 2020-2022".

\section{Постановка проблемы}

В последние годы наблюдалась примечательная тенденция - многие социальные конфликты и протестные события локального (муниципального) уровня довольно часто попадали в федеральную повестку и даже оказывались масштабнее и "шумнее", нежели некоторые протестные акции оппозиции, нацеленные на критику федеральных властей. Протесты в Шиесе против строительства мусорного полигона (июль 2018-9 июня 2020 г.), конфликт сторонников и противников строительства православного храма в сквере у театра драмы в Екатеринбурге (март - июнь 2019 г.), массовое противодействие промышленной разработке горы Куштау в Башкортостане (июнь - август 2020 г.) и многие другие не сильно уступали по масштабу протестным акциям несистемной оппозиции в Москве (например, акции в поддержку А. Навального 23 и 31 января 2021 г.), повестки которых закономерно более масштабны. Существует несколько объяснений подобных обстоятельств. К примеру, локальные вопросы могут восприниматься как более доступные для решения путем уличной политической борьбы. Другое дело понять, о чем данная тенденция может говорить. Свидетельствуют ли указанные события о внезапном появлении сильного гражданского общества на уровне муниципалитетов? Если некоторая активизация действительно наблюдается, то каковы внутренние закономерности этого процесса, какова его динамика имеем ли мы дело с чем-то стремительно растущим или изменения постепенны? Пока недостаточно ясно, почему одни протестные кейсы оказываются успешными для протестующих, а другие нет. Чтобы понять это, следует изучить, как влияют на исход протеста его тематика и предметная направленность. Отметим, что в подавляющем большинстве случаев под конфликтом мы подразумеваем именно протест, инициируемый гражданскими активистами, поэтому далее эти термины будут использоваться как синонимы.

Локальные - городские и муниципальные - конфликты все чаще становятся предметом научного дискурса. Сегодня исследуется:

- какие факторы оказывают провоцирующее воздействие на локальные конфликты (ограниченность ресурсов, невнимание представителей бизнеса и властей к интересам горожан, затруднения в коммуникации между контрагентами [Глухова, 
2019], неспособность представителей власти выполнять роль третьей стороны [Глухова, Кольба, Соколов, 2017], проблемы в законодательстве, декоративный и рекомендательный характер публичных слушаний и т.д. [Медведев, 2017]);

- определяют ли исход конфликтов проходящие параллельно избирательные кампании (есть основания считать, что влияют в пользу протестующих) [Петрова, 2017];

- способствуют ли городские конфликты формированию постоянных гражданских сообществ (делается вывод о значимости конфликта для становления гражданско-политической субъектности локальных сообществ в сфере городской политики [Кольба, Кольба, 2019]);

- эффективны ли публичные слушания как инструмент решения городских споров (это во многом зависит от активности горожан, степени вовлечения общественности в дискуссию [Зуйкина, Никитина, 2018]);

- чем отличаются политизированные и неполитизированные городские конфликты (последние оказываются более "действенными" с точки зрения гражданских активистов [Соколов, Матюшенко, Фролов, 2020]);

- как создается ценность и аутентичность при защите горожанами исторических зданий [Чернышева, Хохлова, 2021];

- каковы рациональные стратегии агентов конфликта, если рассматривать их поведение с позиций теории игр [Семенов, Шевцова, Бедерсон, 2018] и многое другое.

Однако пока, по крайней мере в России, эмпирические исследования локальных (далее мы предпочтем слово “муниципальных") конфликтов ограничиваются преимущественно кейс-стади, которые охватывают один или несколько случаев, что не позволяет делать релевантных обобщений о самом изучаемом феномене. Здесь можно отметить проект по созданию базы данных "Городские конфликты в России", основанный на анализе конфликтных эпизодов (contentious episode analysis, CEA), который впоследствии позволит делать обобщения на больших выборках. А. Семенов и Э. Минаева проанализировали 146 эпизодов городских конфликтов в 15 городах-миллионниках и зафиксировали 1150 взаимодействий акторов, что позволило им выявить территориальную специфику конфликтов [Семенов, Минаева, 2021]. Авторы пришли к выводу, что отмена того или иного неугодного с точки зрения гражданских активистов проекта (уплотнительная застройка, строительство, ведущее к вырубке зеленых насаждений, и т. п.) была достигнута всего в $32 \%$ случаев, тогда как его полная или частичная реализация - в 61\% [там же: 196]. Причем в Москве добиться каких-либо изменений в проекте или его отмены гораздо сложнее, чем, например, в Санкт-Петербурге или Новосибирске. При этом обнаружена четкая связь между контекстуальными характеристиками городов и тематикой протеста, определяющая динамику (интенсивность и последовательность) и исход конфликтных эпизодов. Было продемонстрировано, что вероятность реализации или отмены того или иного "противоречивого" проекта сильно зависит от его тематики: проекты, связанные с уплотнительной застройкой или уничтожением зеленых зон, имеют меньше шансов на воплощение (проекты в два раза чаще отменяются по причине протестов, нежели реализуются), чем инфраструктурные проекты, такие как строительство 
дорог, развязок, трубопроводов. Хуже дела обстоят с застройкой исторического и архитектурного наследия - здесь, напротив, в два раза чаще проекты девелоперов реализуются без изменений. Протесты же против расселения или сноса зданий имеют практически нулевые шансы на успех [там же]. Тем не менее эти, несомненно, значимые результаты не дают полной картины динамики локальных протестов. Во-первых, хронологические рамки исследования А. Семенова и Э. Минаевой достаточно скромны: 2012-2016 гг., что не позволяет делать выводов о тенденциях динамики и интенсивности оспаривания муниципальных территорий. Во-вторых, за основу взяты кейсы городских конфликтов в 15 городах-миллионниках, причем из описания дизайна исследования неясно, каков был принцип отбора самих кейсов. Представляется, что необходимо рассмотреть всю (или как можно большую) совокупность протестных кейсов на большем временном промежутке, сузив при этом географический охват (взяв за конкретные примеры те или иные регионы). Это позволит четче представить динамику, избегая при этом неопределенности критериев выборки.

Другая проблема - концептуальная. Сегодня, как правило, речь идет именно о городских конфликтах. По всей видимости, такой фокус объясним популярной концепцией "права на город" (см., например: [Lefebvre, Harvey, 1991; Харви, 2008]), акцентирующей внимание на столкновении интересов, с одной стороны, горожан, а с другой - власти и бизнеса. Однако неясно, почему речь идет именно о городе, когда многие конфликты на локальном уровне происходят далеко не только в городах, но и в загородных пространствах, оставаясь при этом по своей сути связанными с уничтожением зеленых пространств, с загрязнением окружающей среды, застройкой мест, имеющих культурное значение, и т.д. В общем, неясно, почему город в этом смысле имеет привилегированное значение. Поэтому в данном контексте резонно говорить не о городских конфликтах и не о "праве на город", а о муниципальных конфликтах и о "праве на пространство". Цель настоящего исследования - раскрыть динамику муниципальных конфликтов за последние 15 лет на примере Свердловской области и ответить на вопрос, имеем ли мы дело с какими-то качественными и количественными изменениями конфликтов в современной России на местном уровне.

\section{Метод}

Для достижения поставленной цели выбран ивент-анализ (событийный анализ) - количественный метод исследования, являющийся разновидностью контент-анализа, в рамках которого за единицу анализа берется не слово, а событие. Данный метод, зародившийся в политической науке в 1960-е годы, был нацелен на формализованный анализ взаимодействий между политическими агентами [McClelland, 1967]. Впоследствии его заимствовали исследователи (прежде всего стоит отметить Ч. Тилли [Tilly, 2002]) гражданской мобилизации и протестных событий, стремившиеся оценить их динамику (частоту и уровень интенсивности) в зависимости от тех или иных факторов [McAdam et al., 2005; Семенов, 2018]. Наиболее частая исследовательская стратегия заключается в выявлении и каталогизации тех или иных событий с последующим изучением динамики. Источниками могут быть как полицейские отчеты, так и материалы СМИ. Представляется, что 
преимущество данного метода заключается не только в возможности наглядной визуализации протестных/конфликтных событий, но и в возможности сопровождать чисто количественный анализ качественным, так как не всегда большая величина выборки позволяет углубляться не просто в подсчет встречаемости той или иной единицы анализа, но также смотреть на существенные качественные изменения (например, изменения ключевых агентов гражданской мобилизации, их политической принадлежности и т.д.).

Выбор Свердловской области обусловлен как географической близостью исследователей к происходящим в регионе событиям, так и тем, что Средний Урал представляется репрезентативным для большей части России: здесь есть как относительно развитый постиндустриальный центр (Екатеринбург), представляющий "первую Россию" (Н. Зубаревич ${ }^{1}$ ), так и муниципалитеты с самой разной социально-экономической структурой и статусом — от "Второй России" (Нижний Тагил) до "третьей" (малые моногорода) и "четвертой" (деревни, села и т. д.). В качестве основного поискового источника настоящего исследования выбрано информационное агентство “Ура.ру» (URA.Ru), что обусловлено рядом факторов:

1) это российское информационное интернет-агентство, специализирующееся на новостях Уральского федерального округа и крупнейшее интернет-СМИ Уральского региона;

2) данный ресурс аккумулирует («агрегирует») бо́льшую часть новостей об общественных событиях в Свердловской области, а потому можно уверенно считать, что наиболее важные из них зафиксированы в архивах агентства (как было выяснено в ходе исследования, данный ресурс охватывает далеко не все, но большую часть протестных кейсов, освещая подчас одиночные пикеты, протестные перформансы и небольшие митинги с участием десятков человек);

3) ресурс, судя по характеру материалов, не выглядит ангажированным, освещая события нейтральным языком и предоставляя слово разным с политической точки зрения субъектам (даже если и есть некоторый уклон в сторону оппозиционности, то для исследования протестов это скорее преимущество);

4) ресурс функционирует сравнительно давно, что дает возможность сформировать выборку из большого количества кейсов и проследить динамику на значимом отрезке времени (15 лет²);

5) дизайн сайта позволяет делать внутренние поисковые запросы по архиву и отбирать материал по выбранному региону (Свердловская область).

Разумеется, данный источник применялся преимущественно с целью поиска конфликтных кейсов. При дальнейшем уточнении деталей (субъектов, тематики и результатов того или иного события и т. д.) использовались другие ресурсы, в том числе Znak.com, "Новый день», "Коммерсанть, "Накануне.RU» и др.

B качестве единицы количественного анализа взято конфликтное событие, которое следует отличать от конфликтного кейса. Кейс включает в себя весь набор взаимодействий субъектов по поводу того или иного конфликта, в то время как событие - это единичный значимый «фрагмент» разворачивающегося во времени

\footnotetext{
1 Зубаревич Н. Четыре России и новая политическая реальность // Полит.ру. 2016. 17 января. URL: https://polit.ru/ article/2016/01/17/four_russians/ (дата обращения: 15.08.2021).

2 Точнее-за 15,5 лет, так как в выборку были включены также кейсы до конца июня 2021 г.
} 
кейса, который может быть как непосредственно митингом, пикетом, шествием и т. п., так и новостью о том, что некоторые действия активистов (петиции, обращения в органы государственной власти, выступления на публичных слушаниях и т. д.) оказались в центре внимания СМИ. При этом конфликтным событием было решено считать только конкретные действия, а не комментарии экспертов или заинтересованных сторон, которым посвящались отдельные новостные материалы. Почти все конфликтные события (за исключением нескольких случаев) оказались при этом именно протестными событиями (то есть инициируемыми "снизу»). Один кейс также мог выливаться сразу во множество событий (например, как вышло с борьбой за сквер у театра драмы в Екатеринбурге в 2019 г., когда масштабные митинги длились несколько дней к ряду, что было зафиксировано нами как серия конфликтных событий), хотя такие случаи относительно редки. Акцент именно на событии, а не на кейсе объясняется нами следующим образом: а) так легче количественно сопоставить масштабы протестов (один кейс, выливающийся сразу в несколько событий, как правило, весомее, чем единичное событие), б) так точнее отражается динамика протестной активности, так как один кейс может проявлять себя на протяжении нескольких лет, что лучше визуализировать именно отдельными событиями-проявлениями. К сожалению, такой подход не учитывает точных масштабов конфликтных ситуаций. Небольшая протестная акция из нескольких десятков человек оказывается равнозначной митингу с несколькими тысячами участников. Однако, как будет видно далее, даже такой подход позволяет четко проследить восходящую динамику частоты и уровня интенсивности локальных конфликтов. Как уже было отмечено, параллельно велись качественные наблюдения, позволившие охарактеризовать изменения ключевых субъектов конфликтных ситуаций, их основных тактик и многое другое.

Исследование проводилось в два этапа. На первом этапе осуществлялся поиск и каталогизация конфликтных событий. Поиск проходил в три захода по ключевым словам - «протест", "конфликт" и "митинг". Найденные материалы вручную просматривались step-by-step с целью определения их соответствия критериям выборки. Затем подходящие ссылки на материалы и краткие их описания копировались в единый файл для дальнейшей систематизации и классификации. Каталогизация заключалась в разбивке протестных событий на следующие категории в зависимости от "тематик":

1) парки, скверы, площади, публичные городские пространства;

2) уплотнительная застройка и вопросы межевания и планирования (исключая те, что относятся к п. 1);

3) леса, загородные водоемы, экология и вредные производства;

4) исторические и архитектурные памятники, названия улиц;

5) детские сады и школы;

6) прочее.

В категорию «прочее» были включены конфликты, либо трудно поддающиеся классификации, либо не имеющие достаточного количества аналогов для выделения в отдельную категорию. К примеру, это могли быть случаи, описываемые следующими подзаголовками: “Митинг против „Большого Екатеринбурга“ в Березовском", «Противники реконструкции транспортного кольца у „Исети“ 
в Екатеринбурге переходят к активным действиям", "Краснотурьинск собирает новый митинг за сохранение онкоцентра, который хочет расформировать Белявский", и др. При этом в расчет не были включены некоторые разновидности конфликтов, традиционно ассоциирующиеся с концептом "права на город" (например, протесты против изменения транспортных маршрутов или против отмены прямых выборов мэра).

Такой акцент именно на пространстве объясним особенностями предмета. Во-первых, подавляющее большинство муниципальных конфликтов касаются именно пространства ${ }^{3}$ (так что добавление в выборку "непространственных" исключений не повлияет сильно на конечные результаты). Во-вторых, во многих не попавших в выборку случаях довольно трудно отделить муниципальную повестку от региональной или федеральной. Так, в России отменять выборы мэров начали с 2014 г., когда поправки к законодательству позволили регионам определять форму избрания глав муниципалитетов. К концу 2018 г. от прямых выборов отказались почти во всех регионах. Возникавшие на этом фоне протестные кейсы в итоге сложно классифицировать как местные, так как источник проблемыфедеральный центр. То же касается, скажем, уровня заработной платы и условий труда бюджетников, что далеко не всегда определяется на уровне конкретного муниципалитета. Напротив, вопросы застройки и судьбы той или иной территории пока остаются почти всегда "местными" (если не брать в расчет ооПт ${ }^{4}$ или субъектность региональных отделений федеральных органов надзора), поэтому в качестве исследовательской стратегии в определении предмета был выбран именно пространственный срез.

На втором этапе осуществлялся детальный анализ каждого выявленного кейса. C помощью поисковых запросов в Google и "яндекс" велся поиск информации о причинах того или иного конфликта, его субъектах и итогах. Важно было понять, чем закончилось каждое из попавших в выборку событий, поэтому они разбивались на три группы по их итогам (относительно активистов): "неопределенный результат", "положительный или частично положительный результат в пользу протестующих", "отрицательный результат".

Под "неопределенным" результатом мы понимаем следующее:

1) протест ничем не закончился, так как предмет оспаривания отсутствовал как таковой (реакция на слухи, неподтвержденные намерения девелоперов и т. п.) или требования были слишком общими и расплывчатыми;

2) протест ничем не закончился, так как проект, вызвавший негодование общественности, был свернут по причинам, не зависящим от реакции на протестные события (например, инвестор нашел более подходящее место для вложений или отказался от своего проекта по причине экономического кризиса и т. п.);

3) определить итог конфликта оказалось невозможно (это очень редкие события, но они тоже встречались).

\footnotetext{
з Под "пространством" здесь понимается не просто "промежуток" между объектами, но само “место" (локус), включающее в себя как географические компоненты (природный ландшафт и т.д.), так и соответствующие располагающиеся в его пределах объекты - улицы, площади, парки, здания, памятники, рекламные сооружения и т. п.

${ }^{4}$ Особо охраняемые природные территории (ООПт).
} 
Под "положительным или частично положительным результатом в пользу протестующих" мы понимаем любые протестные события, которые существенно повлияли на исход реализуемого проекта: его либо полностью отменяли, либо откладывали на неопределенный срок, либо сильно видоизменяли, стремясь к компромиссу с активистами. Соответственно, "отрицательный результат" означает, что усилия протестующих оказывались безрезультатными, к их мнению не прислушивались, а заявленные цели протеста достигнуты не были. Наконец, результаты суммировались, сопоставлялись и визуализировались с целью определения общих тенденций.

\section{Результаты}

В ходе исследования выявлено и проанализировано 208 конфликтных событий с 1 января 2006 г. по 31 июня 2021 г. (15,5 лет). Если брать общую выборку без распределения по категориям, то отчетливо видны несколько тенденций (см. рис. 1).

1) После 2010 г. наблюдается резкий подъем конфликтной активности по поводу муниципального пространства, хотя стоит говорить о скачкообразном характере динамики (см. ниже). Правда, этот подъем, как уже было отмечено, показан лишь на количестве конфликтных событий без учета их массовости и масштаба. Такую динамику можно объяснить двумя факторами. Во-первых, к этому времени быстрый рост социальных сетей и дальнейшее развитие коммуникационных технологий облегчили протестную коммуникацию и улучшили осведомленность граждан о событиях муниципального уровня, а во-вторых, заметно влияние массовых протестных акций "За честные выборы" 2011-2012 гг., выразившееся в появлении протестного актива на местном уровне. Эти наблюдения повторяют уже имеющиеся данные по поводу пиков протестной активности в России в 2005 и 2011-2013 гг. [Семенов, 2018: 331]. Так, А. Семенов и Э. Минаева отмечают: "городские конфликты существовали и до кампании „За честные выборы!“ 20112012 гг., однако именно этот эпизод стал поворотным в динамике коллективных действий: с одной стороны, были значительно ужесточены правила проведения публичных собраний и акций протеста, а также введены другие ограничения на общественную деятельность. С другой стороны, в результате появилось множество городских инициатив, непосредственно не связанных с политикой" [Семенов, Минаева, 2021: 194]. Однако не исключено, что отчасти и сами протестные акции стали более "Видимыми" для информационных агентств (хотя в 2008-2009 гг. интернет уже был хорошо развит и широко распространен в нашей стране).

2) Наиболее конфликтным оказался 2019 г., на который пришлись самые массовые конфликтные события за новейшую историю Екатеринбурга: - столкновения сторонников и противников строительства православного храма в сквере у театра драмы (хотя этими событиями "конфликтность" 2019 г. отнюдь не ограничивалась).

3) Спад соответствующей протестной активности в 2020 г. и первой половине 2021 г. объясняется антиковидными ограничениями, когда долгое время были запрещены любые массовые мероприятия (локдаун на протяжении нескольких месяцев). Даже учитывая это, 2020 г. был куда более конфликтным (с точки зрения именно муниципальных конфликтов), чем многие "доковидные» годы. 
4) Несмотря на сказанное выше, трудно заключить, что муниципальные конфликты стали заметны именно в последние годы. Динамика развертывания конфликтов по поводу муниципального пространства свидетельствует о волнообразном характере данного процесса, причем довольно большие «волны" наблюдались в 2011 и 2014 гг.

Рис. 1. Число конфликтных событий по годам
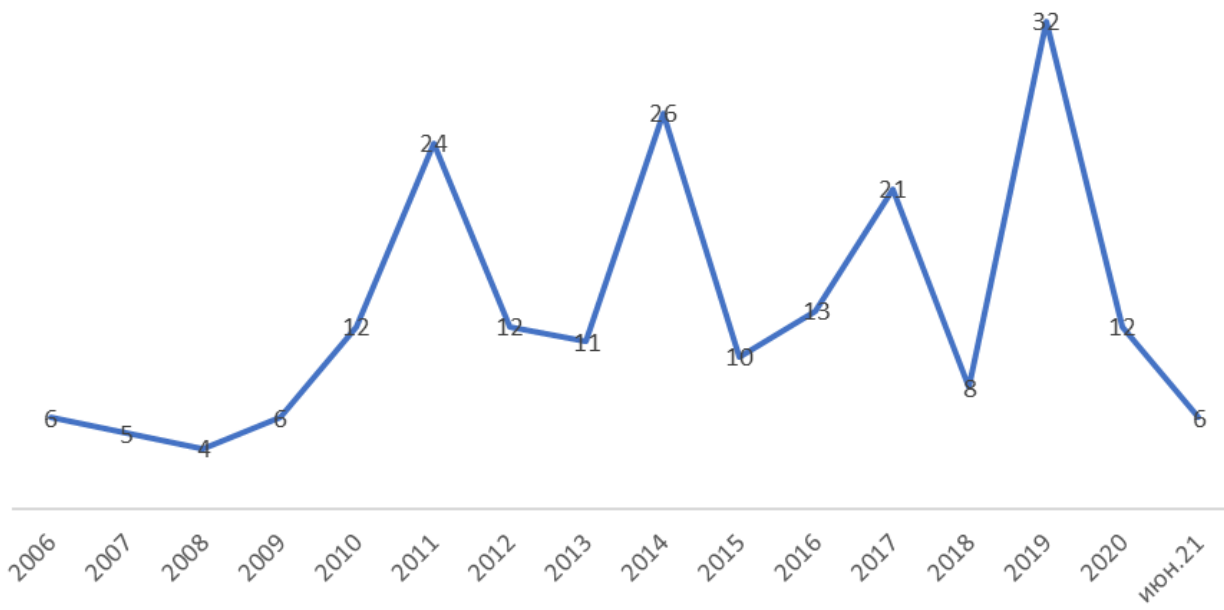

— Конфликтные события

Детализация по тематическим категориям (см. рис. 2) позволяет сделать ряд уточнений:

1) мы видим, что ни в одной из категорий нет устойчивого, последовательного роста или падения конфликтной динамики;

2) в последние годы общую “скачкообразную" восходящую тенденцию демонстрируют конфликты, отнесенные к категориям «Парки, скверы, площади, публичные городские пространства" (именно они сегодня являются наиболее частыми, массовыми и заметными);

3) одна категория конфликтов практически вышла из повестки - "Детские сады и школы»: конфликты из этой категории случались в 2008-2012 гг. (как правило, протесты из-за нехватки детских садов), а потом либо исчезли совсем, либо перестали привлекать внимание СМИ (как минимум, один подобный митинг в 2018 г. "Ура.ру" проигнорировало $\left.{ }^{5}\right)$;

4) наконец, конфликты из категорий «Уплотнительная застройка и вопросы межевания и планирования", "Леса, загородные водоемы, экология и вредные производства", "Исторические и архитектурные памятники, названия улиц", "Прочее" характеризует противоречивая динамика (без какой-либо явной общей тенденции

\footnotetext{
5 Пушкарев И. «Так жить нельзя!» Жители Краснолесья вышли на митинг против нехватки садиков и школ // Znak. com. 2018. 28 Октября. URL: https://www.znak.com/2018-10-28/tak_zhit_nelzya_zhiteli_krasnolesya_vyshli_na_miting protiv_nehvatki_sadikov_i_shkol?utm_source=yxnews\&utm_medium=desktop (дата обращения: 15.08.2021).
} 
к росту или спаду). К примеру, в категории “Леса, загородные водоемы, экология и вредные производства" мы видим два очевидных пика в 2011 и 2014 гг. Причем в 2014 г. конфликты из этой категории были самыми частыми и острыми. Затем наблюдался некоторый спад, но в 2019 г. они оказались на втором месте по встречаемости, хоть и не в том количестве, как это было ранее. Именно такие "зеленые» конфликты, как правило, происходят за пределами крупных мегаполисов (а часто и городов как таковых), что и обусловило сдвиг концептуального фокуса настоящего исследования от "города" к «муниципалитету".

Рис. 2. Количество конфликтных событий по категориям

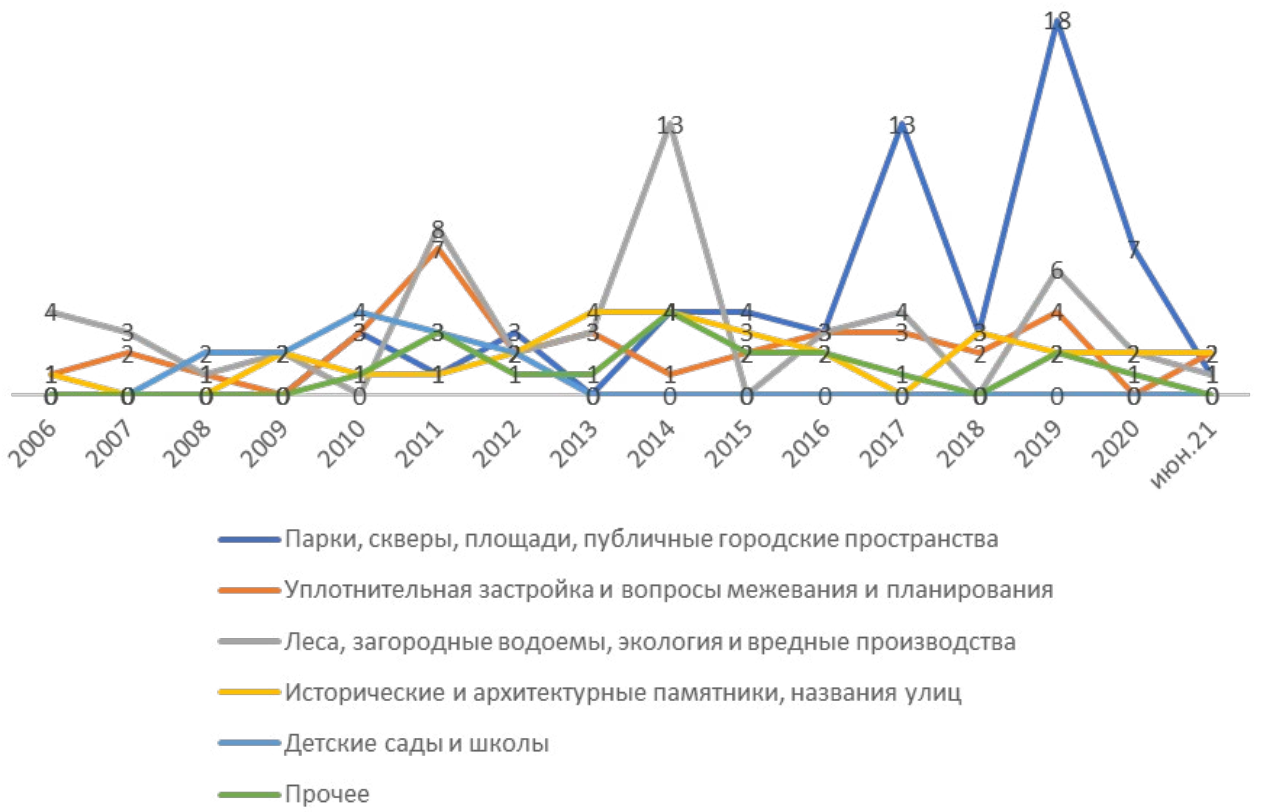

Из 208 конфликтных событий шесть оказались, условно говоря, «провластными" (не протестными) и не были учтены при итоговом подсчете результатов случаев оспаривания муниципальных пространств. 71 событие $(35,2 \%)$ можно отнести к безрезультатным кейсам (“отрицательный результат»). 46 событий (22,8\%) были «неопределенными». При этом 85 событий принесли «положительный или частично положительный результат в пользу протестующих" (42\%). Мы также видим отчетливую тенденцию (см. рис. 3): со временем "эффективность" локальных протестов заметно растет. Так, до 2013 г. результативные протестные акции были исключением из правил. Ситуация резко изменилась в 2014 г., когда Свердловскую область захлестнули экологические протесты (протесты общественности против разработки Юрьевского месторождения, конфликт вокруг добычи золота в Быньгах методом выщелачивания золота цианидом и т. п.), которые оказались в большинстве своем успешными. Также активно росла протестная активность в Екатеринбурге, где развернулась борьба против застройки зеленых 
пространств (конфликт вокруг планируемого строительства "Дома Азербайджана" в Основинском парке и протест против строительства лютеранской кирхи в парке им. Блюхера). Объяснить этот резкий рост “эффективности" достаточно сложно. С одной стороны, налицо рост интенсивности и "медийности" протестов, чему способствовало дальнейшее развитие социальных сетей и распространение среди населения мобильных средств телекоммуникации. Активистам стало проще согласовывать свои действия и развертывать полноценный пул разнообразных атак на все уровни власти (от петиций и сбора подписей до писем губернатору и попыток прорваться на "прямую линию" с президентом). Еще одним объяснением может служить то, что в 2012 г. вернулись выборы губернаторов субъектов РФ. Возможно, это послужило дополнительным стимулом для региональных властей брать на себя инициативу при решении местных споров, что и наблюдалось нами неоднократно, особенно в “экологических" кейсах.

Рис. 3. Количество результативных протестных инициатив на фоне общего числа по годам

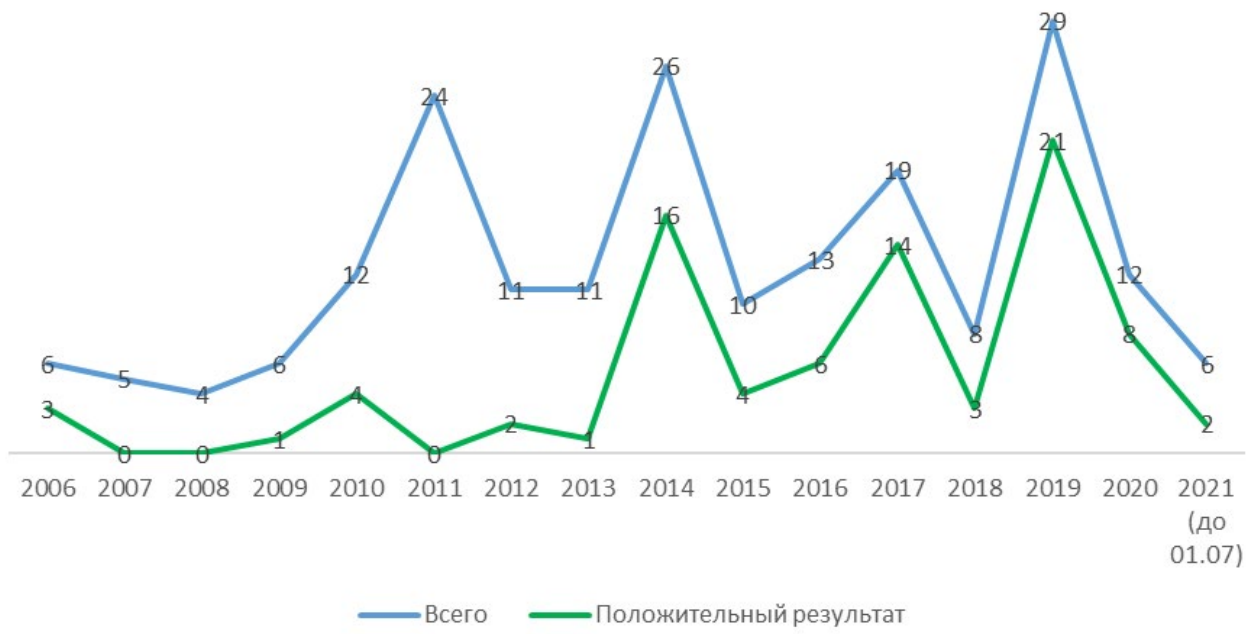

Исследование также показало, что результативность протестного оспаривания городских/муниципальных пространств отличается в разных категориях (см. рис. 4).

Наиболее часто оспариваемыми стали такие места, как парки, скверы, площади, публичные городские пространства, - 55 из 208 конфликтных событий (26,4\%). При этом, как отчетливо видно на диаграмме (см. рис. 4), инициативы защитников парков, скверов, площадей и прочих публичных городских пространств в $80 \%$ случаев сопровождал полный или частичный успех. 
Рис. 4. Итоги протестных инициатив по категориям (\%)

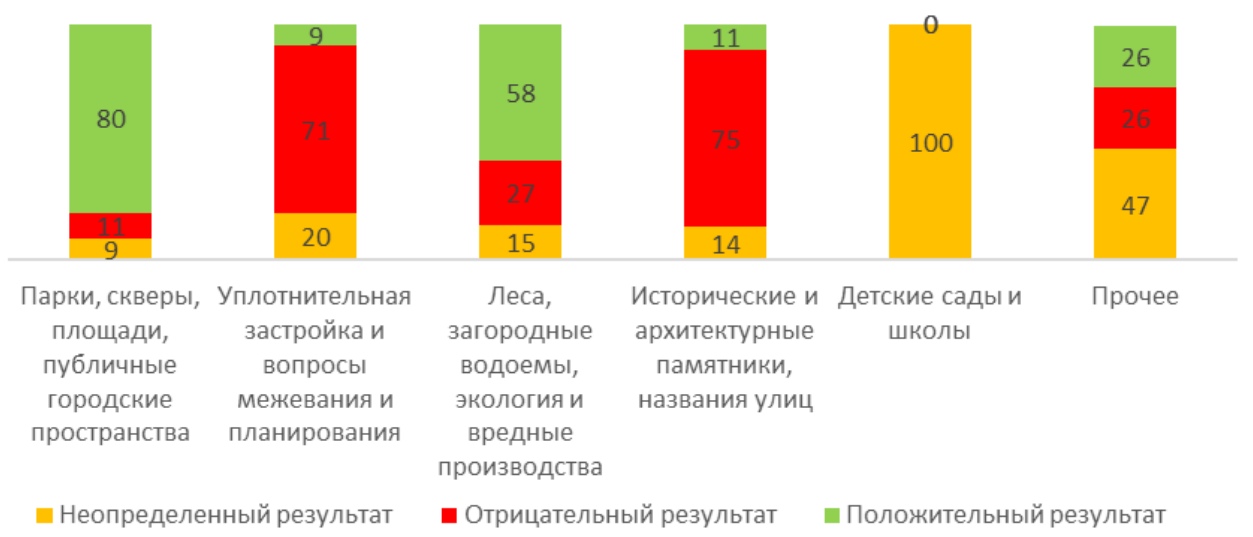

В ситуации с уплотнительной застройкой и вопросами межевания и планирования все обстоит ровным счетом наоборот. Всего конфликтных событий из данной категории мы насчитали 35 (16,8\%), из которых только 8,6\% были "результативными". Эти 8,6\% дали только два кейса. Один "успешный" кейс был связан не с жилищным строительством, а с выбором места для строительства Екатеринбургской кольцевой автодороги (ЕКАД) так, чтобы оно не затрагивало садовые товарищества. Второй кейс охватывал конфликт с планировавшимся в г. Верхняя Пышма строительством двух высотных домов посреди дворов пятиэтажек. Но и в этом случае ключевым "фигурантом" протестного случая не был крупный девелопер, а в качестве цели было обозначено строительство многоквартирных жилых домов для переселения граждан из аварийного жилищного фонда в соответствии с государственной программой. Данное наблюдение весьма примечательно, так как оказывается единственным радикально расходящимся с тем, что обнаружили А. Семенов и Э. Минаева (см. Выше). Возможно, объяснение заключается в том, что у них используются отдельные категории "уплотнительная застройка" и "снос и расселение зданий", в то время как в нашем случае события относились к единой категории “уплотнительная застройка и вопросы межевания и планирования". Однако и это не объясняет столь большой разницы. По всей видимости, Екатеринбург и его пригороды подтверждают свой статус муниципалитетов с максимально "агрессивной" уплотнительной застройкой ("самый компактный" город-миллионник и т. п.). Другое возможное объяснение может заключаться в способе отбора кейсов: мы изучали все возможные протестные события, которые можно было бы отнести к борьбе за городское/муниципальное пространство, в то время как географический размах исследования А. Семенова и Э. Минаевой вряд ли позволил бы сделать нечто подобное. Поэтому в наше поле зрения часто попадали небольшие, но неприятные для местных жителей, конфликты, провоцируемые уплотнительной застройкой. Нам представляется, что гипотеза об относительной "слабости" протеста против уплотнительной застройки более реалистична, так как жильцам прилегающих к оспариваемой территории 
домов, как правило, сложнее реально повлиять на ситуацию, когда "на бумаге" все выглядит идеально. Протестный потенциал жителей нескольких домов ограничен их относительной малочисленностью. К тому же крупные девелоперы имеют необходимые ресурсы для "смягчения" конфликта, например предлагая благоустройство или какие-то еще дополнительные преимущества. Правда обещания в должном виде выполняются не всегда.

Неплохую "эффективность" показали протесты, связанные с вырубкой лесов, загрязнением загородных водоемов, открытием вредных производств и т. п. Всего мы встретили 52 конфликтных события по данной тематике (25\%). Причем 57,7\% из них были связаны с успешными протестными инициативами. 26,9\% не дали никакого результата, а 15,4\% закончились с неопределенным результатом. Стоит отметить, что протесты данного типа с отрицательными результатами наблюдались в основном до 2014 г. (например, безуспешные попытки главы общественной организации "ЭкоЗабота" Александра Клюкина привлечь внимание властей и широкой общественности к экологической обстановке в г. Ревда). После 2014 г. очень редкий протест с экологической повесткой был полностью безрезультатным.

Исторические и архитектурные памятники, а также названия улиц оказываются довольно сложной темой для протестующих, как и уплотнительная застройка. Всего конфликтных событий, отнесенных к данной категории, мы насчитали 28 (13,5\%). Лишь три из них были успешными, причем в одном случае "оспаривающим" субъектом выступала Екатеринбургская епархия, а два других относились к довольно оживленной борьбе (при поддержке КПРФ) жителей Ревды против переноса памятника Ленину с центральной площади города. В остальных же кейсах предметом споров выступали либо полуразрушенные старинные особняки (на содержание которых у муниципалитетов нет необходимых средств), либо такие объекты, которые у жителей вызывают смешанные чувства (к примеру, знаменитая недостроенная телебашня в центре Екатеринбурга, за которую боролись местные урбанисты). Как правило, в таких случаях власти и застройщики пользуются тем, что вопросы культурного наследия беспокоят не самую многочисленную прослойку "креативного класса", урбанистов и прочих неравнодушных к широкой повестке граждан. Протест против совсем абсурдных инициатив властей, конечно, может вызывать общественное негодование (как это было в Верхней Пышме с переименованием улицы Ленина в Успенский проспект, который в народе сразу прозвали "улицей смерти"), но так как такие "символические" вещи не затрагивают напрямую материальные интересы граждан, то и протест в итоге оказывается преимущественно "нематериальным".

Наконец, две последние категории представляются не очень интересными для изучения вне общей выборки. Конфликтные события из категории "детские сады и школы" (всего 13 или 6,25\% из общего числа изученных) оказались самыми "неопределенными" (100\%), поскольку акторы не выдвигали конкретных требований, но акцентировали внимание на общей нехватке детских садов и школ в тех или иных местах. Понять, были ли учтены требования протестующих, в данном случае довольно сложно (возможно, но в общем порядке). В категорию “прочее» (всего 19 или 9,1\% из общего числа изученных) попали очень разные по своему характеру события (от достаточно странных попыток выразить недовольство реконструк- 
цией транспортного кольца у гостиницы "Исеть" в Екатеринбурге, где постоянно возникали пробки, до требования некоторых жителей Первоуральска построить в городе стадион с искусственным льдом для хоккея с мячом). В некоторых случаях проблема с классификацией подобных событий была обусловлена отсутствием конкретики в требованиях (к примеру, протест против "ликвидации" онкоцентра в Краснотурьинске в 2011 г., хотя де-факто речь шла лишь о юридическом объединении с городской больницей). Тем не менее эти события все же составляют неотьемлемую часть борьбы за пространство на локальном (муниципальном) уровне.

Качественный анализ позволил уточнить некоторые моменты и прояснить ряд изменений в муниципальных конфликтах, произошедших за последние 15 лет.

1) Рост действительных масштабов муниципальных конфликтов опережает рост их количества. Чтобы убедиться в этом, достаточно сравнить несколько аналогичных кейсов. Так, вопрос о строительстве Храма Святой Екатерины в центре Екатеринбурга поднимался неоднократно. С ним же связан и первый по-настоящему массовый муниципальный конфликт в городе, произошедший в 2010 г. Тогда, как сообщалось, на митинг за сохранение Площади Труда вышло порядка 6 тыс. человек ${ }^{6}$. Однако такая оценка, мягко говоря, является преувеличением. Сама Площадь Труда не может вместить столько людей, а судя по фотоматериалам, количество участников, присутствовавших в одно и то же время на площади, вряд ли могло превышать 2 тыс. человек (по одной из оценок, там вообще было всего 500 участников ${ }^{7}$ ). Напротив, протесты со схожей повесткой (хотя стоит признать, что в 2010 г. действия администрации и сторонников строительства храма были менее согласованными, а конфликт разгорелся еще до начала реализации проекта) в сквере у театра драмы в мае 2019 г. стали не просто рекордно массовыми (только по оценкам полиции - по 5-6 тыс. человек на протяжении, как минимум, трех дней ${ }^{8}$ ), но и крайне напряженными (столкновения с представителями правоохранительных органов) и "нашумевшими" (вплоть до реакции В.В. Путина 16 мая 2019 г., ${ }^{9}$ что фактически остановило стройку). Другой пример: в 2012 г. борьба защитников торгового центра "Пассаж" против его реконструкции привела к робкому митингу в 150-200 человек ${ }^{10}$ (причем сторонники реконструкции собрали около 5 тыс. участников на собственное шествие ${ }^{11}$, тогда как в 2018 г. аналогич-

\footnotetext{
${ }^{6}$ На митинг за сохранение площади Труда пришло порядка 6 тысяч жителей Екатеринбурга. Такой акции протеста в истории города еще не было. ФОТОрепортаж // URA.RU. 2010. 11 апреля. URL: https://ura.news/news/1052112904 (дата обращения: 15.08.2021).

7 Епархия отреагировала на митинг екатеринбуржцев: «Это попытка сорвать визит патриарха Кирилла». Пресс-служба Викентия сравнила мероприятие с выступлением секс-меньшинств // URA.RU. 2010. 12 апреля. URL: https://ura. news/news/1052112929 (дата обращения: 15.08.2021).

8 Гирш А., Реутова А. Горожане отстояли в сквере // Коммерсанть. 2019. 15 мая. URL: https://www.kommersant.ru/ doc/3968870 (дата обращения: 15.08.2021).

9 Путин предложил опросить жителей района Екатеринбурга о строительстве храма // Forbes. 2019. 16 мая. URL: https://www.forbes.ru/obshchestvo/376185-putin-predlozhil-oprosit-zhiteley-rayona-ekaterinburga-o-stroitelstve-hrama (дата обращения: 15.08.2021).

10 "Пока Мишарин не сказал своего последнего слова, у нас остается надежда!". Горожане вышли на защиту «Пассажа» и разоблачили мэрию: еще Чернецкий подписал отказ от спецстатуса Екатеринбурга // URA.RU. 2012.25 марта. URL: https://ura.news/news/1052141158 (дата обращения: 15.08.2021).

11 «Вы готовы, дети? Да, капитан!» Заводовский и Погребенский ответили защитникам "Пассажа»: устроили в центре Екатеринбурга многотысячное шествие, наплевали на полицию и нечаянно дали слово оппонентам. ФОТО, ВИДЕО // URA.RU. 2012. 21 марта. URL: https://ura.news/news/1052141052 (дата обращения: 15.08.2021).
} 
ный кейс (защита строения, предположительно имеющего культурное значение)защита недостроенной телебашни - вылился в целую серию протестных акций (митинги 26 января и 10 февраля ${ }^{12}$, "прощальные обнимашки" 22 марта $^{13}$, куда предположительно пришло более тысячи человек, попытка "захвата" башни ${ }^{14}$, световые инсталляции и др ${ }^{15}$.).

2) Существенно меняются субъекты конфликтов, в особенности если говорить о протестующей стороне. Во-первых, очевиден постепенный уход на второй план институциональных субъектов, под которыми можно понимать партии и общественные организации. Первый встретившийся нам экологический кейс (2006 г.) был организован депутатом Госдумы от “Единой России" А. Баковым ${ }^{16}$ и явно преследовал цель саморекламы. Затем все чаще встречались конфликты с участием муниципальных и региональных депутатов, а также организованные региональными отделениями КПРФ, ЛДПР и “Справедливой России" (особенно это было актуально для экологических конфликтов в малых городах в 2014 г.). Но чем ближе к сегодняшнему дню, тем реже мы видим в качестве ключевых субъектов протеста депутатов, партии или или общественные движения и чаще - стихийную самоорганизацию активистов, лидеров общественного мнения (например, организаторов групп по интересам в социальных сетях), урбанистов и блогеров. Во-вторых, очевидна тенденция к деперсонализации конфликтов. Так, если говорить о Екатеринбурге, то здесь ранние кейсы в большинстве случаев были ассоциированы с конкретной личностью. Сначала в нескольких кейсах появляется упомянутый выше А. Баков, затем инициатива переходит к депутату Екатеринбургской городской думы от партии "яблоко" М. Петлину, до тех пор, пока в 2011 г. его не обвиняют в вымогательстве в крупном размере (тоже, кстати, связанном с одним из муниципальных конфликтов $\left.{ }^{17}\right)$. Затем часто встречается имя депутата Екатеринбургской городской думы Л. Волкова. После того как Л. Волков уходит работать к А. Навальному в конце 2013 г., центральной фигурой в рассматриваемых конфликтах становится выигравший в том же году выборы мэра Екатеринбурга Е. Ройзман. Но ближе к известным событиям в сквере у театра драмы субъектов протеста становится настолько много, что уже сложно говорить о каком-либо лидере или лидерах. Мы видим как политиков (Е. Ройзман, К. Киселев), так и представителей "креативного класса" и городской богемы (Т. Радя, Н. Коляда), архитекторов и урбанистов (Д. Москвин, В. Злоказов), лидеров мнений в интернете (активистка интернет-сообщества «Парки и скверы Екатеринбурга" А. Балтина), а также эпатажных активистов вроде А. Смышляевой,

${ }^{12}$ Снегирев С. Екатеринбуржцы на митинге собирают подписи в защиту “мечты Ельцина». ФОTO // URA.RU. 2018. 10 февраля. URL: https://ura.news/news/1052323202 (дата обращения: 15.08.2021).

${ }^{13}$ Кулакова О. Сотни екатеринбуржцев "обняли” телебашню перед сносом. “Не взрывай!» ФОTO // URA.RU. 2018. 22 марта. URL: https://ura.news/news/1052328175 (дата обращения: 15.08.2021).

${ }^{14}$ Всех участников акции на телебашне в Екатеринбурге отпустили из полиции // URA.RU. 2018. 23 марта. URL: https://ria.ru/20180323/1517138096.html (дата обращения: 15.08.2021).

${ }^{15}$ На приготовленной к сносу екатеринбургской телебашне лазером написали: «Остановитесь!» (ВИДЕО) // Новый день. 2018. 26 октября. https://newdaynews.ru/ekb/626422.html (дата обращения: 15.08.2021).

${ }^{16}$ См., например: 30 тысяч митингующих, 4 звезды эстрады и 25 кг народного гнева // URA.RU. 2006.17 aпреля. URL: https://ura.news/articles/414 (дата обращения: 15.08.2021).

17 Прокуратура Свердловской области отозвала претензии к знаменитой стройке на Репина. У Максима Петлина не осталось самого сильного аргумента в свою защиту // URA.RU. 2011. 31 марта. URL: https://ura.news/ news/1052127199 (дата обращения: 15.08.2021). 
прославившейся тем, что ее протестный перформанс (уронила забор и залезла на дерево в сквере у театра драмы в день разгоревшегося конфликта, 13 мая 2019 г.) «запустил" цепочку других акций ${ }^{18}$.

3) Наконец, еще одно немаловажное качественное изменение - это усиление протестной “чувствительности", то есть все большее внимание к деталям. До недавних пор конфликты разгорались, как правило, уже на поздних стадиях, когда начиналось строительство или реализация проекта, а суть вопроса касалась самого главного - строить или нет, быть какому-либо объекту или нет. Принципиальной проблемой была потенциальная ликвидация зеленых пространств, парков, детских площадок и т.д. Сегодня конфликт может разгореться уже на стадии обсуждения проекта, причем касаться, скажем, преимущественно эстетических компонентов (например, как конкретно реконструировать парк?), а также мельчайших деталей, вплоть до того, какой должна быть плитка на тротуаре. Так, в 2011 г. в Екатеринбурге разгорелся конфликт, когда Свердловская железная дорога принялась застраивать парк в районе улиц Ватутина, Таежной и Клубного переулка (микрорайон Сортировка). Несмотря на то, что жители микрорайона неоднократно выходили на протестные акции и даже на одной из них сломали забор и позже подожгли будку строителей ${ }^{19}$, это не остановило застройщика и оспариваемое здание Резервного центра обработки СвЖД было в итоге построено. Это сильно контрастирует с современными повестками и с тем, как на них реагируют общественность и муниципальная власть сегодня. К примеру, в июне 2021 г. в Екатеринбурге наблюдался конфликт по поводу реконструкции сквера на улице Опалихинская (Верх-Исетский район). Здесь достаточно привести цитату из соответствующего новостного сообщения, чтобы почувствовать разницу повесток:

Конфликт разгорелся в начале июня. Горожане выразили недовольство, что чиновники начали работы, якобы не согласовав с ними проект благоустройства, хотя к нему есть претензии. В основном протестующие просили заменить покрытие дорожек и площадок с бетонной плитки на асфальт, перенести детские площадки подальше от жилого дома, изменить трассировку велодорожки, а также сохранить деревья от массовой вырубки. 10 июня представители администрации вступили в переговоры с активистами, пригласив их на свою территорию. Мэрия выразила готовность пойти на уступки. Подрядчик начинает реконструкцию той части сквера, по которой нет нареканий [у жителей]. Деревья не будут рубить до согласования [с горожанами]. По поводу замены плитки на асфальт... Нельзя сказать, что есть договоренность, но по крайней мере готовность прозвучала. Также договорились, что скейт-площадку не будут ставить на месте яблонь ${ }^{20}$.

\footnotetext{
${ }_{18}^{18}$ Девушку, которая залезла на дерево на месте будущего храма в Екатеринбурге, проверили на наркотики // URA. RU. 2019. 13 мая. URL: https://ura.news/news/1052383908 (дата обращения: 15.08.2021).

19 В парке на Сортировке, где СвЖД собирается построить себе здание, ночью сгорела будка строителей. Защитники парка: “Мы сами в шоке” // URA.RU. 2011. 17 августа. URL: https://ura.news/news/1052132834 (дата обращения: 15.08.2021).

${ }^{20}$ Аллаяров Д. Мэрия Екатеринбурга пошла на уступки защитникам сквера // URA.RU. 2021. 16 июня. URL: https:// ura.news/news/1052489932 (дата обращения: 15.08.2021).
} 
Это, в сущности, результат борьбы защитников сквера у театра драмы, побудивший представителей городских властей серьезнее относиться к подобным конфликтам. Возможно, причина отчасти и в развитии гражданского общества, представители которого сегодня обладают бо́льшим набором инструментов (интернет, социальные медиа) для продвижения тех или иных повесток.

\section{Обсуждение}

Итак, мы видим несколько трендов. Во-первых, после 2010 г. в Свердловской области наблюдается общий подъем количества конфликтов по поводу муниципального пространства. Правда, этот рост является сбивчивым, “скачкообразным", сильно зависящим от конкретных информационных повесток. Во-вторых, растет и интенсивность, массовость данных конфликтов. Эти тенденции могут быть объяснены рядом факторов. Прежде всего стоит говорить о бурном развитии социальных медиа, передавших в руки местным активистам весомые инструменты мобилизации и утверждения повестки дня (сюда можно отнести и рост прослойки персоналиата [Давыдов, 2020] - лидеров мнений разных мастей и масштабов, легко приводящих в движение городскую публику). Параллельно шло активное формирование гражданского общества и политической оппозиции со своими лидерами, идеями и пр. (Л. Волков, скажем, станет одной из ключевых фигур в движении А. Навального). Один из возможных факторов, требующих отдельного изучения, может заключаться в увеличении темпов городской застройки, благоустройства и в целом в росте инвестиций в те или иные территории, что неизбежно ведет к столкновению интересов.

По всей видимости, активисты, оспаривающие муниципальные территории, будут чаще добиваться поставленных целей. Это видно и по визуализации нашего исследования, и по тому, как менялось отношение властей к защите жителями зеленых пространств. Однако мы считаем, что такая условная и частичная "победа" протестующих в отдельно взятом регионе - это еще не решение всех имеющихся проблем в сфере оспаривания муниципальных территорий. Представителям региональных властей стоит внимательнее относиться к вопросам уплотнительной застройки и проблемам сохранения исторических и архитектурных памятников. Пока это еще относительно "спокойные" категории протестов (не в смысле отсутствия недовольства, которое как раз растет, а в смысле способностей представителей бизнеса и власти эти протесты подавлять или игнорировать), но со временем все может сильно измениться, и вопросы сноса исторических памятников или переименования улиц для очень многих станут принципиальными (так, осенью 2021 г. в Екатеринбурге разгорается конфликт из-за сноса старого аэропорта Уктус, построенного в 1937 г.) $)^{21}$.

Полученные результаты также свидетельствуют об отчетливой тенденции, которую можно обозначить как постепенный переход от практического к эстетическому: все реже в центр внимания местной общественности попадают проблемы сугубо «насущные», располагающиеся в непосредственной близости от места проживания и касающиеся комфорта, здоровья, доступности тех или иных благ;

\footnotetext{
${ }^{21}$ На защиту аэропорта Уктус в Екатеринбурге вышли 30 человек // URA.RU. 20 ноября. 2021. URL: https://ura.news/ news/1052517911 (дата обращения: 21.11.2021).
} 
и все чаще - вопросы, затрагивающие эстетику и историко-культурную ценность городского пространства. Одно дело, когда люди протестуют из-за нехватки мест в детских садах или по причине возведения на детской площадке многоэтажного дома, который при этом еще и перекрывает естественное освещение. Совсем другое дело, когда жители массово протестуют из-за сноса уродливой недостроенной телебашни, считая ее культурным достоянием. То же можно сказать о зеленых зонах. Существует большая разница между протестом из-за вырубки деревьев в близлежащем парке, участниками которого становятся преимущественно жители соответствующего микрорайона (к примеру, как это было в 2012 г. при протесте против возведения областной станции юннатов в парке 50-летия ВЛКСМ в районе улиц Ясная и Шаумяна в Екатеринбурге ${ }^{22}$ ), и защитой сквера в 2019 г. как общегородского достояния и как публичного пространства, имеющего не только сугубо утилитарное, но и во многом символическое значение. Эту тенденцию легко заметить по тому, как растет количество протестов из категорий «Парки, скверы, площади, публичные городские пространства" и "Исторические и архитектурные памятники, названия улиц" (особенно в относительном выражении, см. выше). Одно из потенциальных объяснений - то, что Р. Инглхарт (см., например, [Inglehart, 2018]) обозначил как тенденцию к вытеснению "материалистических" ценностей постматериалистическими. Суть данного наблюдения заключается в том, что по мере экономического развития классовая борьба по поводу распределения материальных благ теряет актуальность, а люди, обеспеченные всем необходимым, предпочитают бороться за гражданские права и свободы, а также думать об экологии в "общечеловеческих" масштабах (глобальное потепление, сохранение природного разнообразия и т. п.). Думается, что сюда можно отнести и упомянутое выше "право на город" (шире - «право на пространство»), ведь эстетическая и культурно-историческая ценность пространства - это как раз то, о чем могут думать люди, не испытывающие острой нужды в повседневных благах. Конечно, трудно говорить о доминировании постматериалистических ценностей в стране в целом. Однако для того, чтобы та или иная протестная повестка поднималась вновь и вновь, этого и не требуется, так как протесты инициируются, как правило, небольшим сообществом городских активистов.

\section{Ограничения}

Наше исследование имеет ряд ограничений, связанных с методом и выборкой. Возможно, Свердловская область с уникальным масштабным кейсом (борьба за сквер у театра драмы в 2019 г.) может отличаться по протестной динамике от других регионов. Дальнейшие исследования могли бы прояснить этот вопрос. В частности, можно попытаться сравнить регионы с разными социальноэкономическими и демографическими показателями. Определенные лимиты имеет и тип используемого информационного источника - региональные интернет-СМИ. К сожалению, специфика развития интернета не позволяет брать более широкие временные промежутки, охватывая более давние кейсы. Возможно,

\footnotetext{
22 Участники митинга против возведения станции юннатов в Собачьем парке, в котором принимали участие VIP, пошли на штурм строительного забора. ФОТО // URA.RU. 2012. 13 июля. URL: https://ura.news/news/1052145133 (дата обращения: 15.08.2021).
} 
перспективной была бы методология, комбинирующая интернет-СМИ и традиционные источники вроде бумажных газет, что требует серьезных трудозатрат. Тем не менее представляется, что настоящее исследование позволило выделить ряд универсальных тенденций, масштабы которых, правда, еще предстоит оценить с помощью дальнейших поисков.

\section{Заключение}

По результатам настоящего исследования можно сделать ряд выводов. Проведенный ивент-анализ показал, что после 2010 г. в Свердловской области наблюдается резкий подъем конфликтной активности по поводу муниципального пространства. При этом сугубо городскими конфликтами наблюдаемые кейсы не ограничиваются. Немалое количество конфликтных событий было зафиксировано по поводу определения судьбы загородных пространств (леса, национальные парки, реки и т. п.). Исследование показало, что в последние годы чаще всего конфликты разгораются вокруг таких пространств, как парки, скверы, площади и прочие публичные городские места. Конфликты из категорий "Уплотнительная застройка и вопросы межевания и планирования", "Леса, загородные водоемы, экология и вредные производства", "Исторические и архитектурные памятники, названия улиц", "Прочее" характеризует противоречивая динамика (без какойлибо явной общей тенденции к росту или спаду). При этом была обнаружена тенденция к росту результативности локальных протестов: после 2013 г. доля результативных протестов резко растет и становится преобладающей. Правда, успех борьбы гражданских активистов против инициатив бизнеса и власти («машины роста") сильно зависит от того, с какого типа территориями и объектами они имеют дело. Наибольшая доля "успешных" протестов наблюдается в случаях борьбы за парки, скверы, площади, публичные городские пространства, а также за леса, загородные водоемы и против вредных производств. Минимальная вероятность успеха отмечается у протестов против уплотнительной застройки и за сохранение исторических и архитектурных памятников. Учитывая возросший интерес у протестующих (в том числе урбанистов) к мельчайшим деталям оспариваемых проектов и эстетической составляющей городского пространства, можно прогнозировать, что локальные конфликты, скорее всего, будут тематически связаны преимущественно с зелеными пространствами и историко-культурной ценностью тех или иных объектов и территорий (что можно объяснить "постматериалистическими" ценностями и интересами городской богемы, урбанистов, блогеров как наиболее активной части населения и т. п.). Поэтому сочетание "спроса на эстетику" и обнаруженной нами слабой реакции бизнеса и власти на протесты за сохранение исторических и архитектурных памятников представляется одним из сохраняющихся рисков роста протестной активности. Дальнейшие исследования на более широкой выборке или с использованием другого типа информационных источников позволят проверить и уточнить выдвинутые гипотезы. 


\section{Список литературы (References)}

Глухова А. В. Городские конфликты в современной России: Новая предметность в старом контексте // Logos et Praxis. 2019. T. 18. № 3. C. 148-155. https:// doi.org/10.15688/Ip.jvolsu.2019.3.16.

Glukhova A. V. (2019) City Conflicts in Modern Russia: A New Issue in the Old Context. Logos et Praxis. Vol. 18. No. 3. P. 148-155. https://doi.org/10.15688/ Ip.jvolsu.2019.3.16. (In Russ.)

Глухова А. В., Кольба А. И., Соколов А. В. Политико-институциональные и коммуникативные аспекты взаимодействия субъектов городских конфликтов (по материалам экспертного опроса) // Человек. Сообщество. Управление. 2017. Том 18. № 4. C. 44-65. URL: http://chsu.kubsu.ru/arhiv/2017_4/2017_4_ GlukhovaKolbaSokolov.pdf (дата обращения: 20.12.2021).

Glukhova A. V., Kolba A. I., Sokolov A. V. (2017) Political —Institutional and Communicative Aspects of Interaction of Subjects of Urban Conflicts (Based on Expert Survey). Human. Community. Management. Vol. 18. No. 4. P. 44-65. http://chsu.kubsu.ru/arhiv/2017_4/2017_4_GlukhovaKolbaSokolov.pdf (accessed: 20.12.2021). (In Russ.)

Давыдов Д. А. Чей протест? Посткапиталистическая трансформация и антиномии "низовой" политической борьбы // Общественные науки и современность. 2020. № 5. C. 21-37. https://doi.org/10.31857/S086904990011119-2.

Davydov D. A. (2020) Whose Protest? Post-Capitalist Transformation and Antinomies of "Grassroots" Political Struggle. Social Sciences and Contemporary World. No. 5. P. 21-37. https://doi.org/10.31857/S086904990011119-2. (In Russ.)

Зуйкина А. С., Никитина В.Л. Публичные слушания: процедурные правила и результаты проведения (на примере города Перми) //Ars Administrandi (Искусство управления). 2018. Т. 10. № 3. С. 502-518. http://dx.doi.org/10.17072/ 2218-9173-2018-3-502-518.

Zuikina A. S., Nikitina V. L. (2018) Public Hearings: Procedural Rules and Results (Based on the Example of Perm City). Ars Administrandi. Vol. 10. No. 3. P. 502-518. http:// dx.doi.org/10.17072/2218-9173-2018-3-502-518. (In Russ.)

Кольба А. И., Кольба Н. В. Городские конфликты как фактор гражданско-политической активизации локальных сообществ // Политическая наука. 2019. № 2. C. 160-179. http://dx.doi.org/10.31249/poln/2019.02.08.

Kolba A. I., Kolba N.V. (2019) Urban Conflicts as a Factor of the Local Communities' Civil - Political Activation. Political Science (RU). No. 2. P. 160-179. http://dx.doi.org/ 10.31249/poln/2019.02.08. (In Russ.)

Медведев И. Р. Разрешение городских конфликтов. М.: Инфотропик Медиа, 2017. Medvedev I.R. (2017) Resolution of Urban Conflicts. Moscow: Infotropic Media. (In Russ.)

Петрова Р.И. Политизация городских конфликтов в современной России: участники, повестка, тактическое взаимодействие // Вестник Пермского университета. Политология. 2017. № 3. С. 122-136. 
Petrova R. I. (2017) Politicization of Urban Conflicts in Modern Russia: Participants, Agenda, Tactical Interaction. Bulletin of Perm University. Political Science. No. 3. P. 122-136. (In Russ.)

Семенов А. Событийный анализ протестов как инструмент изучения политической мобилизации // Социологическое обозрение. 2018. Т. 17. № 2. С. 317-341. https://doi.org/10.17323/1728-192X-2018-2-317-341.

Semenov A. (2018) Protest Event Analysis as a Tool for Political Mobilization Studies. Russian Sociological Review. Vol. 17. No. 2. P. 317-341. https://doi.org/10.17323/ 1728-192X-2018-2-317-341. (In Russ.)

Семенов А. В., Минаева Э. Ю. Города расходящихся улиц: развитие городских конфликтов в России 2010-х // Журнал исследований социальной политики. 2021. T. 19. № 2. C. 189-204. https://doi.org/10.17323/727-0634-2021-19-2-189-204. Semenov A. V., Minaeva E. Yu. (2021) The Cities of Forking Streets: Trajectories of Urban Conflicts in Russia. The Journal of Social Policy Studies. Vol. 19. No. 2. P. 189-204. https://doi.org/10.17323/727-0634-2021-19-2-189-204. (In Russ.)

Семенов А. В., Шевцова И. К., Бедерсон В.Д. Городская мобилизация и градостроительная политика: стратегическое взаимодействие местных жителей и застройщиков в ситуации конфликта // Журнал социологии и социальной антропологии. 2018. T. 21. № 3. C. 140-169. https://doi.org/10.31119/jssa.2018.21.3.7.

Semenov A. V., Shevtsova I. K., Bederson V.D. (2018) Urban Mobilization and Urban Development: Strategic Interactions between Residents and Developers in a Conflict. Journal of Sociology and Social Anthropology. Vol. 21. No. 3. P. 140-169. https:// doi.org/10.31119/jssa.2018.21.3.7. (In Russ.)

Соколов А. В., Матюшенко Д.В., Фролов А.А. Политизированные и неполитизированные городские конфликты: особенности и характер развития (на примере Ярославской области) // ПоИСК: Политика. Обществоведение. Искусство. Социология. Культура. 2020. Т. 2. № 79. С. 49-59.

Sokolov A. V., Matyushenko D. V., Frolov A. A. (2020) Politized and Nonpoliticized Urban Conflicts: Features and Nature of Development (On the Example of the Yaroslavl Region). POISK: Politics. Social Studies. Art. Sociology. Culture. Vol. 2. No. 79. P. 49-59. (In Russ.)

Харви Д. Право на город // Логос. 2008. Т. 3. № 66. С. 80-94.

Harvey D. (2008) The Right to the City. Logos. Vol. 3. No. 66. P. 80-94. (In Russ.)

Чернышева Л.А., Хохлова А. М. Создавая ценность и аутентичность: городские конфликты вокруг исторических зданий // Журнал исследований социальной политики. 2021. Т. 19. № 2. С. 223-238. https://doi.org/10.17323/727-06342021-19-2-223-238.

Chernysheva L. A., Khokhlova A. M. (2021) Creating Value and Authenticity: Urban Conflicts Around Historical Buildings. The Journal of Social Policy Studies. Vol. 19. No. 2. P. 223-238. https://doi.org/10.17323/727-0634-2021-19-2-223-238. (In Russ.) 
Inglehart R. F. (2018) Cultural Evolution: People's Motivations are Changing, and Reshaping the World. Cambridge: Cambridge University Press. https://doi.org/ 10.1017/9781108613880.

Lefebvre H., Harvey D. (1991) The Production of Space. Bulgaria: Wiley.

McAdam D., Sampson R. J., Weffer-Elizondo S., Maclndoe H. (2005) "There Will Be Fighting in the Streets": The Distorting Lens of Social Movement Theory. Mobilization. No. 10. P. 1-18.

McClelland C. A. (1967) Event-Interaction Analysis in the Setting of Quantitative International Relations Research. Mimeo: University of Southern California.

Tilly C. (2002) Event Catalogs as Theories. Sociological Theory. Vol. 20. No. 2. P. 248254. https://doi.org/10.1111/1467-9558.00161. 